\title{
Dividend Policy of Jordanian Firms: Stability Tests and Survey Results
}

\author{
Hadeel Yaseen ${ }^{1}$, Ghassan Omet ${ }^{2} \&$ Bashar Abu Khalaf $^{2}$ \\ ${ }^{1}$ Finance and Banking Department, Applied Science Private University, Jordan \\ ${ }^{2}$ Faculty of Business, Dept. of Finance, University of Jordan, Jordan \\ Correspondence: Hadeel Yaseen, Finance and Banking Department, Applied Science Private University, Jordan. \\ E-mail: h_yassin@asu.edu.jo
}

Received: June 11, 2015

Accepted: July 6, 2015

Online Published: July 25, 2015

doi:10.5539/ibr.v8n8p72

URL: http://dx.doi.org/10.5539/ibr.v8n8p72

\begin{abstract}
The aim of this study is to examine listed Jordanian firms in terms of the issue of dividend policy stability. In more specific terms, the paper complements the econometric analysis of dividend stability with a survey of the Chief Financial officers (CFOs). Based on a total of 40 industrial firms and the time period 2002-2013, the results of the panel data analysis indicate that Jordanian firms follow stable dividend policy. In addition, the survey results support the econometric conclusions. Based on the results of this paper, it is recommended that future research should examine the issue of what really determines the dividend policy of Jordanian firms. In addition, given the fact that the industrial firms follow stable dividend policy, it would be extremely interesting to investigate whether or not these firms manage earnings in order to meet their dividend stability objective.
\end{abstract}

\section{Highlights:}

- Examining listed Jordanian industrial firms in terms of if the firms adopt stable dividend policy?

- The results reveal that the sample of firms do follow stable dividend policy Do Chief Financial officers' (CFOs) views on dividend policy support or contradict the actual behaviour of dividend policy?

Keywords: Amman securities exchange, dividend policy, clientele effect, stability, survey

\section{Introduction}

Standard textbooks teach students that the subject matter of corporate finance deals with three long-term financial decisions. First, in what real assets should firms invest? Second, how firms determine their structure of capital? Third, what proportion of their net incomes should firms distributing in the form of cash or stock dividend to their shareholders?

To give answers to the above-mentioned financial decisions, corporate finance has developed a myriad of concepts and techniques to help financial managers in the process of maximizing firms' stock prices. These include, for example, capital budgeting techniques, optimal capital structure, cost of equity capital, the weighted average cost of capital, and many others.

As far as dividend policy is concerned, the classical literature provides us with two viewpoints. First, based on the arguments put forward Miller and Modigliani (1961) dividends policy has no impact on the value of firms. Indeed, this view is supported by Black (1976) whom declared that the harder we look at the dividends image, the further it seems similar to a puzzle with pieces that just don't fit mutually. In contrast, Gordon (1959) and Lintner (1956) argue that dividend policy is an important determinant of stock price.

Irrespective which argument is more relevant, it is interesting to note that the "empirical evidence on whether dividend policy affects a firm's value offers contradictory advice to corporate managers" (Baker et al., 2011). These contrasting views have led to the publication of many papers that examine dividend policy. This literature, it can be argued, relies on three main approaches. The first approach relies on econometric analysis of what determines dividend policy. The second approach relies on questionnaires whose aim is to understand how chief financial officers set the dividend policy of their firms. Finally, the third approach examines whether or not firms follow stable dividend policy.

Relative to the above brief account of dividend policy, this paper examines listed Jordanian industrial firms in 
terms of two questions:

(1) Do firms adopt stable dividend policy?

(2) Do Chief Financial officers' (CFOs) views on dividend policy support or contradict the actual behaviour of dividend policy?

The rest of the research is structured as follows. Section 2 in brief reviews the relevant literatures. In section 3, the data and methodology, and empirical results are presented and discussed. Finally, the last section summarizes and concludes.

\section{Dividend Policy: Literature Review}

The issue of dividend policy has managed to keep its important standing in the finance literature. Indeed, this puzzling financial decision has led to the formulation of many theories. These include the bird in the hand theory, agency costs, firm life cycle, asymmetric information and signaling, tax and clienteles, and the catering theory. These, and other theories, have resulted in the publication of many empirical papers. Indeed, the number is too large to review in any single paper. However, this literature can be classified under three main approaches.

The first approach uses econometric analysis of published financial data to test one or more hypotheses. In other words, typically this literature regresses a measure of dividend policy on a set of variables including company profitability, firm leverage, size, growth opportunity, and firm liquidity. In addition, this econometric analysis includes tax rate, systematic risk, legal constraints, structure of ownership, and market power as possible determinant of dividends policy. To name but a few, this literature includes Bhattacharya (1979), Aharony and Swany (1980), Asquith and Mullins (1983), DeAngelo et al. (1996), Benartzi et al. (1997), Grinstein and Michaely (2005), Amidu and Abor (2006), Barclay et al. (2009), Afza and Mirza (2010), Gill et al. (2010), Thanatawee (2013), Booth and Zhou (2015), and many others. Relative to this literature, it is useful to note that Baker and Weigand (2015) provide a review of the literature which concerns dividend policy.

The second approach relies on surveys of financial officers. Based on pioneering work by Graham and Harvey (2001), many papers examine whether or not financial officers use the recommended tools, techniques, and concepts, including dividend policy, explained in standard finance textbooks. Some of the American survey studies are Gitman and Forrester (1977), Moore and Reichert (1983), Poterba and Summers (1995), Shao and Shao (1996), Bodnar et al. (1998), Bruner et al. (1998), and Graham and Harvey (2001). Surveys of executive views on finance issues in the UK, Australia, New Zealand, Singapour, Hong Kong, Indonesia, Thailand, and Ireland have also been carried out. These studies include Kester et al. (1999), and Parry (2001), Dhanani (2005), McCluskey (2007). In addition to the above, more recent papers have also been published including those by Troung et al. (2006), Butt et al. (2010), Mutairi et al. (2012), Baker et al. (2013), and Ozo et al. (2015).

The third approach follows the publication of the classic paper by Lintner (1965) which examines the stability of dividend policy. In other words, this paper attempts to examine if companies do not tend to increase dividends unless they believe that the increase in their profits is "permanent". This finding has also been supported by many papers including Cheung and Roy (1985), Lowntein and Kato (1995), Lasfer (1996), Dewenter and Warther (1998), Aivazian (2001), Nisim and Ziv (2001), Farsio et al. (2004), Amiedu (2007), Howat et al. (2009), Ajanthann (2013), Leon and Putra (2014), and Tran et al. (2014).

As far as the stability issue of dividend policy is concerned, the empirical literature estimates two main models and these are referred to as the Lintner Model (1956) and Fama and Babiak Model (1968). These are outlined below.

$$
\begin{gathered}
D P S_{i, t}=\alpha_{1}+\beta_{1} E P S_{i, t}+\beta_{2} D P S_{i, t-1}+\varepsilon_{i, t} \\
D P S_{i, t}=\alpha_{1}+\beta_{1} E_{P S}+\beta_{2, t} D P S_{i, t-1}++\beta_{3} E P S_{i, t-1}+\varepsilon_{i, t}
\end{gathered}
$$

where DPS is the dividends per share (i) in time period t, EPS is earnings per share.

Based on the estimated results, the literatures conclude that firms pursue stable dividends policy if the coefficients of the lagged value of dividend per share (DPS) are positive and statistically significant. In other words, this positive coefficient implies that firms do not increase (decrease) their dividend per share unless they think the increase (decrease) in their net income is permanent.

As mentioned above, the Lintner (1956), Fama and Babiak (1968) model have been estimated by many researchers. On average, this literature provides plenty of evidence whoch shows that firms do follow stable dividend policy. However, within this aspect, it is interesting to note that few papers reported high instability in dividend policy including that published by Adaoglu (2000). Based on the time period 1985-1997 and a total of 76 industrial and commercial listed Turkish firms, it is stated that "any variability in the earnings of the 
corporation is directly reflected in the level of cash dividends. In other words, earnings instability results in instability in dividends" (Adaoglu, 2000).

\section{The Data, Methodology and Empirical Results}

To examine dividend policy in terms of its stability aspect, the researchers examined the dividend per share of all listed industrial firms ( 65 in total) and managed to collect the necessary data for a total of 40 firms during the period 2002-2013. Based on this time period 2002-2013, these firms (40) had a total of at least 8 years of cash dividends.

Naturally, the inclusion of firms with zero dividend per share would bias the estimation results. However, following Dwenter and Warther's (1998) methodology, the presence of 8 years out of 13 years positive dividend per share is chosen so that the estimated coefficients would not "suffer" from the zero dividend per share. Based on this principle, the analysis is based on a total of 480 balanced observations.

The classical paper by Lintner (1956) put forward the following model:

$$
\begin{gathered}
T D i, t=r_{i} P_{i, t} \\
T D_{i, t}-D_{i, t-1}=\alpha_{i}+c_{i}\left(T D_{i, t}-T D_{i, t-1}\right)+\varepsilon_{i, t}
\end{gathered}
$$

where $\mathrm{TD}_{\mathrm{i}, \mathrm{t}}$ is the target and optimum level of dividend in time period t of a company $i$, and $r_{i}$ is the targeted payout ratios, $\mathrm{P}_{\mathrm{i}, \mathrm{t}}$ is the rank of net profit, $\mathrm{D}_{\mathrm{i}, \mathrm{t}}$ is the real dividend imbursement in time period $\mathrm{t}$, and $\varepsilon_{\mathrm{i}, \mathrm{t}}$ is the error term.

Expression (4) implies that dividend payment do not adjust to their optimum level immediately. This adjustment process is partial. Also, the positive constant $\alpha_{\mathrm{i}}$ indicates that firms are unwilling to cut dividend. The coefficient $\left(\mathrm{c}_{\mathrm{i}}\right)$ indicates that dividends policy is stable and also implies that firms may not desire to instantly alter dividend payments to the target ratio $\left(r_{i}\right)$. If we merge expression 3 and expression 4 , we can write the following expression:

$$
T D_{i, t}=\alpha_{i, t}+b P_{i, t}+d T D_{i, t}+\varepsilon_{i, t}
$$

where $\mathrm{b}$ is equal to $\mathrm{cr}$ and $\mathrm{d}$ is equal (1-c). In addition, and to test the stability of dividend policy, expression 5 can be re-written as:

$$
D P S_{i, t}=\alpha_{1}+\beta_{1} E P S_{i, t}+\beta_{2} D P S_{i, t-1}+\varepsilon_{i, t}
$$

As previously stated, if the coefficient $\left(\beta_{2}\right)$ is positive and statistically significant, one can conclude that firms do follow stable policy.

In Table 1 and Figure 1, we report the overall mean values of dividend per share and earnings per share and their annual mean values respectively. On average, the mean values of dividend per share $(0.150)$ and earning per share (0.232) imply that our sample of firm distributed about 65 percent of their net income in the form of cash dividends. In addition, it is interesting to note the annual fluctuations in both dividend per share and earning per share (Figure 1). Clearly, the Figure reflects the observation that earning per share fluctuates more than dividend per share. Indeed, the maximum and minimum mean annual values of earning per share are equal to 0.344 and 0.211 respectively. The maximum and minimum values of dividend per share, on the other hand, are equal to 0.181 and 0.143 .

Table 1. Divided per share and earnings per share: basic statistics

\begin{tabular}{ccc}
\hline & DPS & EPS \\
\hline Mean & 0.150 & 0.232 \\
Median & 0.100 & 0.150 \\
Maximum & 1.500 & 1.962 \\
Minimum & 0.000 & -0.671 \\
Std. Deviation & 0.186 & 0.297 \\
\hline
\end{tabular}




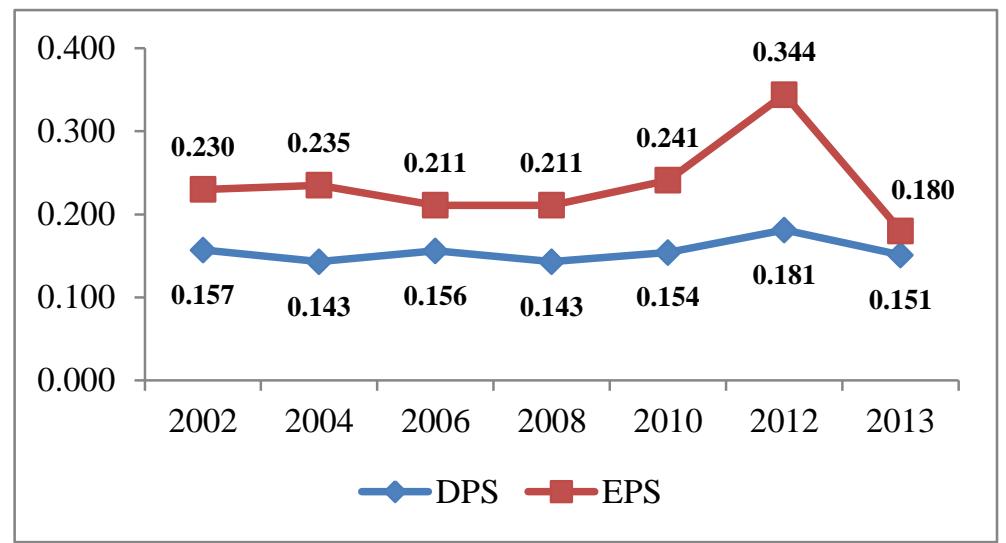

Figure 1. Annual DPS and EPS

The estimates of Lintner's, Fama and Babiak's models are presented in Table 2. This Table reveals a number of interesting findings.

First, the reported results reveal that the constant term is consistently positive and significant. This result indicates that the sample of firms is reluctant to reduce their dividend per share. Indeed, this is consistent with the original finding of Lintner (1956).

Second, as far as the coefficient of the lagged dividend per share is concerned, again, it is consistently positive and statistically significant. While these findings imply that firms do follow stable policy, it is important to note that the speed of adjustment is equal to 0.414 (Lintner model) and 0.370 (Fama and Babiak model). These values are higher than the 0.30 reported by Lintner (1956) for US firms and the 0.33 reported by Brav et al. (2005) for US firms (1984-2002), and lower than the 0.71 reported by Pandey and Bhat (2007) for Indian firms, and the 1.00 reported by Adaoglu (2000) for Turkish firms. The fact that high rapidity of adjustments indicates lesser smoothing and a lesser amount of stability, we can conclude that our sample of firms do follow stable dividend policy.

Finally Table 2 reveals the observation that our sample of companies that have a target dividend payout ratio equal to 0.659 (Lintner model) and 0.721 (Fama and Babiak model). These ratios are higher than the 0.50 reported by Lintner (1956), and the 0.459 reported by Fama and Babiak (1968) and close to the 0.697 reported by AlYahyaee et al. (2010) for Omani companies.

Table 2. Regression results: fixed-effect model

\begin{tabular}{ccc}
\hline & Lintner Model & Fama and Babiak Model \\
\hline Variable & Coefficient & Coefficient \\
C & $0.035^{* *}$ & $0.030^{* * *}$ \\
EPS & $0.273^{* *}$ & $0.267_{* *}^{* *}$ \\
DPS(-1) & $0.341^{*}$ & $0.279^{*}$ \\
EPS(-1) & ------- & $0.065^{* * *}$ \\
Adjusted R & 0.749 & 0.752 \\
D-W Statistic & 2.237 & 2.108 \\
F-Statistic & $27.203^{*}$ & $26.955^{*}$ \\
Target Payout Ratio & 0.659 & 0.721 \\
Speed of Adjustment & 0.414 & 0.370 \\
\hline
\end{tabular}

Note. *, **,*** signify significance at the 99 percent, 95 percent, and 90 percent levels respectively.

In addition to the above econometric analysis of the stability issue of dividend policy, and based on the existing (survey) studies, we developed a survey and distributed it to the CFOs of the 40 industrial firms. To assess the 
CFOs views on dividend policy, they were asked to point out their level of contract with a number of statements that are based on a five point scale. To develop the reaction rate, all the CFOs were then track up with a phone call and later on by a individual appointment to gather the "filled" photocopy of the review. In Table 3, we report the main findings. Based on the reported mean values, the following comments can be provided.

Table 3. Dividend policy: levels of agreement

\begin{tabular}{|c|c|c|c|c|c|c|}
\hline & & Disagree & & $\rightarrow$ & Agreement & \\
\hline Statement & 0 & 1 & 2 & 3 & 4 & Mean \\
\hline Dividend payout affects share price & $0 \%$ & $3 \%$ & $22 \%$ & $40 \%$ & $35 \%$ & 3.07 \\
\hline Firm should maintain uninterrupted dividends & $1 \%$ & $2 \%$ & $15 \%$ & $46 \%$ & $36 \%$ & 3.14 \\
\hline $\begin{array}{l}\text { Reason for dividends policy changes should be explained to } \\
\text { shareholders }\end{array}$ & $2 \%$ & $11 \%$ & $14 \%$ & $41 \%$ & $32 \%$ & 2.90 \\
\hline Dividends payments is a signal mechanism of firm projection & $5 \%$ & $27 \%$ & $19 \%$ & $24 \%$ & $25 \%$ & 2.37 \\
\hline $\begin{array}{c}\text { Dividend announcements are used by the market in determining } \\
\text { share prices }\end{array}$ & $2 \%$ & $5 \%$ & $18 \%$ & $41 \%$ & $34 \%$ & 3.00 \\
\hline $\begin{array}{l}\text { Management must be responsive to owners' attitudes towards } \\
\text { dividend policy }\end{array}$ & $6 \%$ & $8 \%$ & $20 \%$ & $25 \%$ & $41 \%$ & 2.87 \\
\hline $\begin{array}{c}\text { Financing new investment projects must be secured before } \\
\text { dividend distributions }\end{array}$ & $3 \%$ & $10 \%$ & $31 \%$ & $37 \%$ & $19 \%$ & 2.59 \\
\hline
\end{tabular}

Note. The mean scores are designed by multiplying the $\%$ in each category with values 0 throughout 4 for ratings strongly disagree to strongly agree.

First, the CFOs scale the importance of dividend payout ratio relatively high (mean of 3.07). In other words, dividend payout is relevant.

Second, as far as the stability of dividend policy is concerned, we find that 82 percent of the CFOs agree that the company should adopt uninterrupted dividend payments. Indeed, the mean value of this statement is the highest (3.14).

Third, we find that 73 percent of the respondents agree with the statement that any changes in dividend policy must be explained to shareholders (clientele effect). An implication of this (clientele effect) is that the residual policy should not be adopted. Indeed, such a policy (residual) results in unstable dividend policy.

Finally, when we asked the CFOs whether new investment projects' finance must be secured before any dividend distributions, we find that the mean value of this statement is the lowest (2.59). This observation complements the responses that support dividend policy stability.

\section{Summary and Conclusions}

This paper examined a total of 40 listed Jordanian industrial firms in terms of the stability issue of their dividend policy. Based on the time period 2002-2013 and panel data analysis, the results reveal that the sample of firms do follow stable dividend policy. Furthermore, the survey questionnaire supports this empirical finding.

Based on the results of this paper, it is recommended that future research should examine the issue of what really determines dividend policy of Jordanian firms. In other words, factors like firm leverage, size, growth opportunity, firm liquidity, systematic risk, and ownership structure can be considered as possible determinants of dividend policy. Finally, the fact that our sample of industrial firms follows stable dividend policy, it would be extremely interesting to investigate whether or not these firms manage their earnings. Indeed, such management may be adopted to meet their dividend stability objective.

\section{References}

Adaoglu, C. (2000). Instability in the dividend policy of the Istanbul stock exchange ISE corporations: Evidence from an emerging market. Emerging Markets Review, 1, 252-270. http://dx.doi.org/10.1016/S1566-0141(00)00011-X

Afza, T., \& Mirza, H. (2010). Ownership structure and cash flows as determinants of corporate dividend policy 
in Pakistan. International Business Research, 3(3), 180-187. http://dx.doi.org/10.5539/ibr.v3n3p210

Aharony, J., \& Swany, I. (1980). Quarterly dividend and earnings announcements and stockholder returns: An empirical analysis. Journal of Finance, 35, 1-12. http://dx.doi.org/10.1111/j.1540-6261.1980.tb03466.x

Aivazian, V., Booth, L., \& Cleary, S. (2001). Dividend policy in developing countries (pp. 1-42). Paper presented at the Eighth Annual Conference, Multinational Finance Conference, Italy.

Amidu, M., \& Abor, J. (2006). Determinants of dividend payout ratios in Ghana. Journal of Risk Finance, 7(2), 136-145. http://dx.doi.org/10.1108/15265940610648580

Asquith, P., \& Mullins, D. (1983). The impact of initiating dividend payments on shareholders' wealth. Journal of Business, 56, 77-96. http://dx.doi.org/10.1086/296187

Baker, H., \& Weigand, R. (2015). Corporate dividend policy revisited. Managerial Finance, 2, 126-144. http://dx.doi.org/10.1108/MF-03-2014-0077

Baker, H., Farrelly, G., \& Edlean, R. (2013). A survey of management views on dividend policy. Financial Management, 14, 78-84. http://dx.doi.org/10.2307/3665062

Baker, H., Singleton, J., \& Veit, E. (2011). Survey research in corporate finance-Bridging the gap between theory and practice. New York, NY: Oxford University Press.

Barclay, M. J., Holderness, C. G., \& Sheehan, D. P. (2009). Dividends and corporate shareholders. Review of Financial Studies, 22(6), 2423-2455. http://dx.doi.org/10.1093/rfs/hhn060

Benartzi, S., Michaely, R., \& Thaler, R. (1997). Do changes in dividends signal the future or the past? Journal of Finance, 52, 1007-1034. http://dx.doi.org/10.1111/j.1540-6261.1997.tb02723.x

Bhattacharya, S. (1979). Imperfect information, dividend policy, and the bird-in-hand phallacy. Journal of Economics, 10, 259-270.

Black, F. (1976). The dividend puzzle. Journal of Portfolio Management, 2, 5-8. http://dx.doi.org/10.3905/jpm.1976.408558

Bodnar, G., Hayt, G., \& Mertson, R. (1998). Wharton survey of financial risk management by U.S. non-financial firms. Financial Management, 27, 70-91. http://dx.doi.org/10.2307/3666414

Booth, L., \& Zhou, J. (2015). Market power and dividend policy. Managerial Finance, 2, 145-163.

Brav, A., Graham, J., Harvey, C., \& Michaely, R. (2005). Payout policy in the 21st century. Journal of Financial Economics, 77, 483-527. http://dx.doi.org/10.1016/j.jfineco.2004.07.004

Bruner, R., Eades, K., Harris, R., \& Higgins, R. (1998). Best practices in estimating the cost of capital: Survey and synthesis. Financial Management, 27, 1328.

Butt, B., Hunjra, A., \& Rehman, K. (2010). Financial management practices and their impact on organizational performance. World Applied Sciences Journal, 9, 997-1002.

DeAngelo, H., DeAngelo, L., \& Skinner, D. (1996). Reversal of fortune: Dividend policy and the dissappearance of sustained earnings growth. Journal of Financial Economics, 40, 341-371. http://dx.doi.org/10.1016/0304-405X(95)00850-E

Dewenter, K., \& Warther, V. (1998). Dividends, asymmetric information, and agency conflicts: Evidence from a comparison of the dividend policies of Japanese and US firms. Journal of Finance, 53, 879-904. http://dx.doi.org/10.1111/0022-1082.00038

Dhanani, A. (2005). Corporate dividend policy: The views of British financial managers. Journal of Business Finance \& Accounting, 60, 3-43. http://dx.doi.org/10.1111/j.0306-686x.2005.00643.x

Gill, A., Biger, N., \& Tibrewala, R. (2010). Determinants of dividend payout ratios: Evidence from United States. Open Business Journal, 3, 8-14. http://dx.doi.org/10.2174/1874915101003010008

Gitman, L., \& Forrester, J. (1977). A survey of capital budgeting techniques used by major U.S. firms. Financial Management, (Fall), 66-71. http://dx.doi.org/10.2307/3665258

Gordon, M. (1959). Dividends, earnings and stock prices. Review of Economics and Statistics, 2, 99-105. http://dx.doi.org/10.2307/1927792

Graham, J., \& Harvey, C. (2001). The theory and practice of corporate finance: Evidence from the field. Journal of Financial Economics. http://dx.doi.org/10.1016/S0304-405X(01)00044-7 
Grinstein, Y., \& Michaely, R. (2005). Institutional holdings and payout policy. Journal of Finance, 60, 1389-1426. http://dx.doi.org/10.1111/j.1540-6261.2005.00765.x

Kato, K., \& Lowentein, U. (1995). The ex-dividend -day behaviour of stock prices: The case of Japan. Review of Financial Studies, 8, 817-847. http://dx.doi.org/10.1093/rfs/8.3.817

Kester, G., Chang, R., Echanis, E., Haikal, S., Isa, M., Skully, M., Kai-Chong, T., \& Wang, C. (1999). Capital budgeting practices in the Asia-Pacific region: Australia, Hong Kong, Indonesia, Malaysia, Philippines, and Singapore. Financial Practice and Education, Spring/Summer, 7-15.

Lasfer, M. (1996). Taxes and dividends: The UK evidence. Journal of Banking and Finance, 20, 455-472. http://dx.doi.org/10.1016/0378-4266(95)00012-7

Lintner, J. (1956). Distribution of incomes of corporations among dividends, retained earnings and taxes. American Economic Review, 46, 97-133.

McCluskey, T., Burton, B., \& Power, D. (2007). Evidence on Irish financial directors' views about dividends.

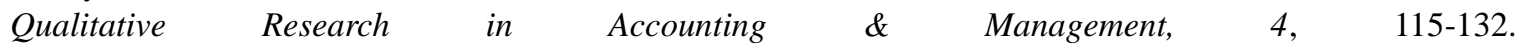
http://dx.doi.org/10.1108/11766090710754196

Miller, M., \& Modigliani, F. (1961). Dividend policy, growth, and the valuation of shares. Journal of Business. 34, 411-433. http://dx.doi.org/10.1086/294442

Moore, J., \& Reichert, A. (1983). An analysis of the financial management techniques currently employed by large U.S. corporations. Journal of Business Finance and Accounting, 10, 623-645. http://dx.doi.org/10.1111/j.1468-5957.1983.tb00456.x

Mutairi, M., Tian, G., Hasan, H., \& Tan, A. (2012). Corporate governance and corporate finance practices in a Kuwait stock exchange market listed firms: A survey to confront theory with practice. Corporate Governance, 12, 595-615. http://dx.doi.org/10.1108/14720701211275523

Pandey, I., \& Bhat, R. (2007). Dividend behaviour of Indian companies under monetary policy restrictions. Managerial Finance, 23, 14-25. http://dx.doi.org/10.1108/03074350710715782

Parry, J., Black, C., Anderson, H., \& Bennett, J. (2001). Are New Zealand chief financial officers the poor cousins of their American counterparts? Departmental Working Paper Series (WP 01.1), Masey University, New Zealand.

Porterba, J., \& Summers, L. (1995). A CFO survey of U.S. companies' time horizon and hurdle rates. Sloan Management Review, Fall, 43-53.

Roy, S., \& Cheung, J. (1985). Target payout and the association between dividends and share prices. Accounting and Finance, 25, 57-76. http://dx.doi.org/10.1111/j.1467-629X.1985.tb00140.x

Shao, L., \& Shao, A. (1996). Risk analysis and capital budgeting techniques of U.S. multinational enterprises. Managerial Finance, 22, 41-57. http://dx.doi.org/10.1108/eb018542

Thanatawee, Y. (2013). Life-cycle theory and free cash flow hypothesis: Evidence from dividend policy in Thailand. International Journal of Economics and Finance, 5(1), 121-132.

Troung, G., Partington, G., \& Peat, M. (2006). Cost of capital estimation and capital budgeting practice in Australia. Finance Discipline, School of Business, University of Sydney, Australia.

Yahuaee, K., Pham, T., \& Walter, T. (2010). Dividend policy in a unique environment. Managerial Finance, 36, 903-916. http://dx.doi.org/10.1108/03074351011070260

\section{Copyrights}

Copyright for this article is retained by the author(s), with first publication rights granted to the journal.

This is an open-access article distributed under the terms and conditions of the Creative Commons Attribution license (http://creativecommons.org/licenses/by/3.0/). 